
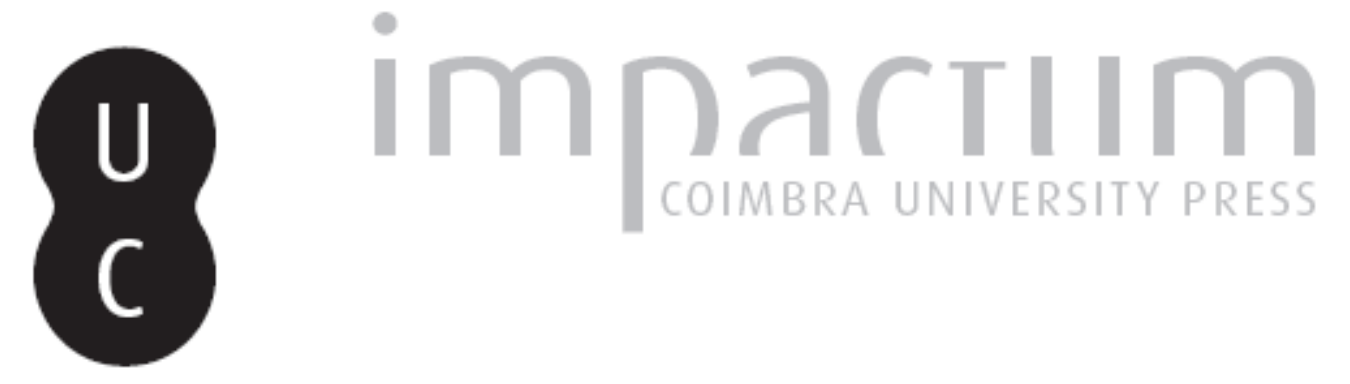

\title{
[Recensão a] José Frederico Laranjo - Economistas Portugueses. Subsídios para a história das doutrinas económicas em Portugal
}

Autor(es): $\quad$ Pereira, José Esteves

Publicado por: Imprensa da Universidade de Coimbra

URL persistente:

URI:http://hdl.handle.net/10316.2/43966

DOI:

DOI:https://doi.org/10.14195/2183-8925_2_13

Accessed : $\quad$ 26-Apr-2023 05:34:37

A navegação consulta e descarregamento dos títulos inseridos nas Bibliotecas Digitais UC Digitalis, UC Pombalina e UC Impactum, pressupõem a aceitação plena e sem reservas dos Termos e Condições de Uso destas Bibliotecas Digitais, disponíveis em https://digitalis.uc.pt/pt-pt/termos.

Conforme exposto nos referidos Termos e Condições de Uso, o descarregamento de títulos de acesso restrito requer uma licença válida de autorização devendo o utilizador aceder ao(s) documento(s) a partir de um endereço de IP da instituição detentora da supramencionada licença.

Ao utilizador é apenas permitido o descarregamento para uso pessoal, pelo que o emprego do(s) título(s) descarregado(s) para outro fim, designadamente comercial, carece de autorização do respetivo autor ou editor da obra.

Na medida em que todas as obras da UC Digitalis se encontram protegidas pelo Código do Direito de Autor e Direitos Conexos e demais legislação aplicável, toda a cópia, parcial ou total, deste documento, nos casos em que é legalmente admitida, deverá conter ou fazer-se acompanhar por este aviso.

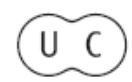


INSTITUTO DE HISTÓRIA E TEORIA DAS IDEIAS

\title{
REVISTA DE HISTÓRIA $D A S$ IDEIAS
}

\author{
VOL. II
}

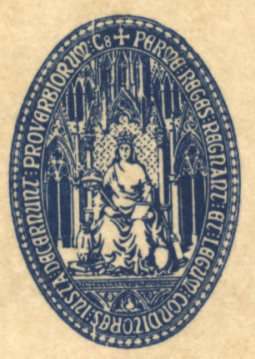

UNIVERSIDADE DE COIMBRA

$1978-1979$ 
suas possibilidades teóricas de um absolutismo racionalista) o papel condicionador, director e obstaculizador também, por indistinção político-sociológica. Nesse aspecto, parecem-nos correctas as palavras com que Carlos da Fonseca encerra o seu estudo: «Não se improvisam industriais, sobretudo se os pretendentes são agentes da tirania do capital comercial».

Esperemos, portanto, que os dois tomos da Bibiloteca de Economistas tenham a continuidade desejável e se atenda, também, à urgente necessidade da publicação de inéditos, de molde a criar um corpo textual para a investigação, sem descurar o papel eminentemente pedagógico que os textos portugueses de res aconomica têm a desempenhar.

JosÉ Esteves Pereira

\section{José Frederico Laranjo - Economistas Portugueses. Subsídios para a história das doutrinas económicas em Portugal. Prefácio e notas de Carlos da Fonseca, Lisboa, Guimarães \& C. ${ }^{\text {a }}$, Editores, 1976, $132 \mathrm{pp}$.}

Com prefácio e notas de Carlos da Fonseca, apareceram, em 1976, reunidos em volume, os artigos que José Frederico Laranjo publicou em «O Instituto», entre 1881 e 1884 , sobre alguns economistas portugueses.

A apresentação do lente de Economia Política compõe-se, além de notas sobre o autor, de um esquema diacrónico e sincrónico da história das doutrinas económicas em Portugal, que, embora discutível na sua arrumação, ganha importância pela possibilidade de assim se proceder a um útil estudo comparativo.

Carlos da Fonseca chama a atenção no seu estudo introdutório para o facto de Frederico Laranjo (1846-1910) fundar, entre nós, os estudos de história do pensamento económico, na linha de um apelo que entronca em José Ferreira Borges. Mas, quanto a isso, parece-nos que Ferreira Borges, prolonga apenas um outro aspecto que não é, necessariamente ainda, o de uma história da economia, do processo económico liberal, mas sim o fenómeno mais enraizado da consciência cientificadora do económico, da economia política como disciplina axial. E quanto a este aspecto o problema é em Portugal, anterior a José Ferreira Borges.

Manifestou-se em preocupação, em 1789, aquando da polémica do Novo Código, depois mais intensamente de 1879 a 1815 na Memórias Económicas da Academia das Ciências de Lisboa, em 1803 com as Memórias Politicas de Joaquim José Rodrigues de Brito, e no ciclo vintista, com activa promoção legislativa. E, no que concerne aos fisiocratas da Academia, achamos talvez exagerado escrever que «a persistência das relações pré-capitalistas durante o século XVIII e primeira metade do século XIX, limitaram os horizontes teóricos dos economistas portugueses, geralmente incapazes de originalidade, de inovação doutrinal, balbuciando tímidas propostas de «regeneração económica», ou desembocando num empirismo tecni- 
cista e sem talento" (Introdução, p. 14). Para além do maior ou menor entendimento teórico da fisiocracia, das teses de Quesnay, de Gournay, de Le Mercier de la Rivière, de Dupont de Nemours, ou de muitos outros, e atentos ao facto de que os nossos teóricos fisiocratas vivem numa época de maquinofactura, lêm Smith, e têm perante si a macrocefalia comercialista e o atraso estrutural global do país, não podemos deixar de ver em muitas das suas intervenções o resultado, mais da perplexidade do que da falta de talento ou da menor aplicação a uma arquitectura de doutrina.

Os fisiocratas portugueses estavam predispostos a efectivas transformações, embora seja necessário inserir o seu labor intelectual e prático nas concepções do absolutismo polemizado em 1789, do influxo legislativo e executivo pombalino, e do esforço de permeabilização de uma mentalidade receptiva a transformações técnicas do espaço português, de levantamento estrutural e de adequação à prática do pendor politécnico que a Universidade pombalina, através da Faculdade de Filosofia, ia tomando.

Carlos da Fonseca aflora, também, na sua Introdução, o tema da fixação da taxa de juros - tema candente da história do pensamento económico português até ao século XIX, pelas incidências morais e políticas de que se revestiu - e que encontrou tratamento significativo por parte do fisiocrata Tomás António Vila Nova Portugal.

José Esteves Pereira

\section{Bartolomé Bennassar - L'homme espagnol. Attitudes et mentalités du XVI ${ }^{e}$ siècle au XIXe siècle, Paris, Hachette, 1975, $252 \mathrm{pp}$.}

O título do livro é esclarecedor quanto ao objectivo do autor. E igualmente, quanto à área da História em que o mesmo se situa. Por um lado, Bartolomé Bennassar pretende desenhar o perfil do «homem espanhol»; por outro, é sobre história das mentalidades que vai escrever.

É evidente que a finalidade do livro - livro, diga-se, desde já, extremamente interessante e imaginativo - põe, no tocante à sua execução, dificuldades várias; dificuldades que aumentam, ao pensar-se nos próprios óbices que a história das mentalidades, dada a sua natureza, pode levantar quanto à sua própria teorização. Concretamente, por um lado, quanto à metodologia a seguir na "captação» da realidade histórica que é a sua, por vezes, femininamente esquiva e movente por nela confluirem temas e problemas que, não sendo os seus, deles não pode, no entanto, prescindir; por outro, quanto à própria inteligibilidade da realidade histórica sobre que se debruça, quando a construção, não podendo dispensar a intuição e a argúcia, terá sempre racionalmente que fundar aquelas, sob pena de se fazer, não obra científica de história, mas, tão-só, obra jornalística (e má), senão obra mais ou menos fantasiosa. 